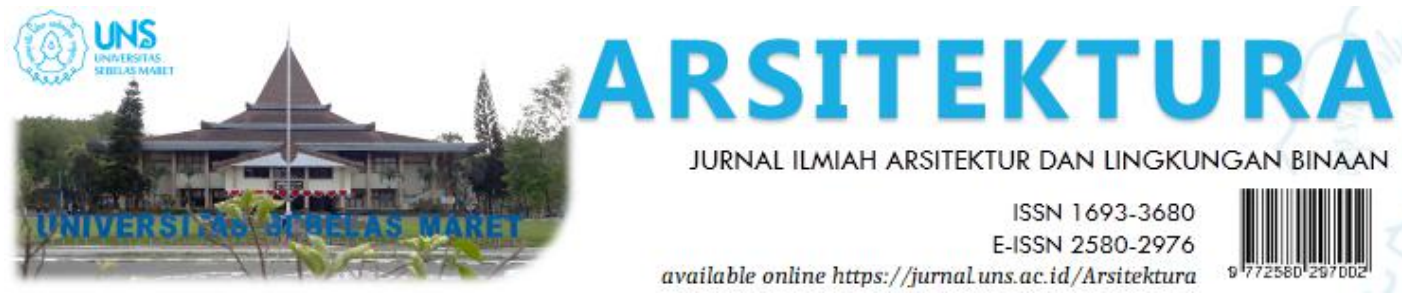

Volume 17 No 2 October 2019, pages:293-302

\title{
Model Pengembangan Kampung Wisata Blangkon di Surakarta Berbasis Konsep Kearifan Lokal
}

\section{Model of Blangkon Tourism Kampoeng Development in Surakarta based on Local Wisdom Concepts}

\author{
Bambang Triratama $^{1 *}$, Yosafat Winarto ${ }^{2}$, Sri Yuliani ${ }^{3}$ \\ Architecture Department, Faculty of Engineering, Universitas Sebelas Maret ${ }^{1 *}$ \\ Email : triratmab@yahoo.co.id * \\ Architecture Department, Faculty of Engineering, Universitas Sebelas Maret ${ }^{2}$ \\ Architecture Department, Faculty of Engineering, Universitas Sebelas Maret $^{3}$
}

DOI: https://doi.org/10.20961/arst.v17i2.24532

Received: October 10, 2018 Revised: October 5, 2019 Accepted: October 5, 2019 Available online: October 31, 2019

\begin{abstract}
Blangkon is a product of local wisdom that has high heritage value as a part of a Javanese traditional costume since the kingdom period of Surakarta. To increase durability and sustainability the blangkon home industries have to adapt to trend development. The research aims to build a model of tourism village based on local wisdom. The method of phenomenology observation was applied to find aspects that have a good opportunity to be integrated directly and indirectly with the product and production of blangkon. The fusion of those two aspects became a part of tourism activities in Surakarta and The Province of Central Java. The result of research leads to some important conclusions. The product and production of blangkon have to be integrated harmoniously with some other aspects and activities especially those based on local wisdom in order to build and to save the blangkon becoming an important heritage matter and commodity. Finally, the model of tourism village based on local wisdom has to be built by involving the local community to guarantee they are going to get a better life in the future. It has three main parts, namely components, management and sustainability of the model.
\end{abstract}

Keywords: tourism village, local wisdom, model of village development, sustainable development

\section{PENDAHULUAN}

Kearifan lokal telah menjadi satu komponen penting saat ini tidak hanya dalam kepentingan konservasi obyek cagar budaya tetapi juga dalam upaya kemanfaatan saat ini dan mendatang berkaitan dengan pengembangan proses dan produk budaya serta ketahanan produk rancang bangun kawasan
(Zahnd,2008). Produk-produk berbasis kearifan lokal dalam berbagai bentuk dan kepentingan telah terbukti mempunyai daya tahan terhadap dinamika multi sektor yang ekstrim dibanding produk kekinian.

Namun demikian dalam beberapa kondisi dan situasi, kearifan lokal dengan segala manifestasinya mengalami degradasi dan 
ketersisihan ketika berhadapan dengan dinamika tumbuh kembang komponen kekinian sebagai konsekuensi tuntutan pergerakan jaman. Beberapa faktor penyebab perlu dicari dan kemudin diperhatikan untuk menguatkan kembali potensi kelokalan tersebut.

Fenomena tersebut terjadi di salah satu kawasan industri rumahan blangkon di Kelurahan Serengan Kecamatan Serengan Kota Surakarta. Keberlangsungan industri rumahan blangkon telah mengalami degradasi sejak 20 th terakhir. Beberapa upaya telah dilakukan namun belum membawa perbaikan yang signifikan. Bebepa upaya tersebut belum ada ysng mengarah pada penyatuan yang sinergis beberpa kemungkinan prospektif menuju satu pemodelan. upaya telah dilakukan namun belum membawa perbaikan yang signifikan. Beberapa upaya tersebut belum ada yang mengarah pada penyatuan yang sinergis beberapa kemungkinan prospektif menuju satu pemodelan.

Kampung wisata merupakan salah satu bentuk wahana yang berusaha mengakomodasi upaya menumbuh-kembangkan suatu kampung dengan memanfaatkan potensi yang terkandung di dalamnya (Tosun, 2000). Potensi inilah yang kemudian menjadikan penciri bentuk akhir dari konsep masingmasing kampung tersebut, ada kampung wisata kuliner, kampung wisata batik.

Pengembangan kampung wisata berbasis komunitas atau community based development (Setyaningsih, 2015) merupakan model lain suatu upaya membangun kampung berbasis potensi dan partisipasi komunitas sedemikian sehingga membentuk suatu dinamika kegiatan wisata yang mendatangkan keuntungan bagi banyak pihak. Potensi dan partisipasi komunitas tersebut dapat dipahami dalam 2 hal, dari sisi manusia dan karyanya (Sutedjo,1985). Sisi manusia berkaitan dengan keahlian sebagai pemicu lahirnya produk dalam berbagai wujud berupa karya.

Surakarta merupakan salah satu kota dengan latar belakang tumbuh kembang berbasis sejarah yang sangat segnifikan dalam tataran lokal, regional, dan nasional, divisualkan pada Gambar 1 dan Gambar 2. Beberapa periode pembentuk kronologi mewakili perjalanan peradaban manusia sejak jaman purba hingga searang (Sidharta \& Budihardjo,1989). Sangiran merupakan jejak asal mula peradaban manusia terletak tidak jauh dari kota. Era kehidupan kemudian yaitu periode kerajaan berawal dari kepindahan Keraton Kartasura ke Desa Solo akibat peristiwa Geger Pecinan th 1670, merupakan era kehidupan kerajaan tradisional. Masuknya Bangsa Belanda dengan bendera VOC menandai periode penjajahan kompeni di Surakarta. Interaksi multi etnis seperti Bangsa Arab, Cina, Barat menjadi latar belakang tubuh kembang budaya baik fisik maupun non fisik. Periode berikutnya adalah berlatar belakang dinamika bangsa Indonesia dalam memperjuangkan dan memuli kehidupan sebagai bangsa yang merdeka. Dinamika interasi beberapa aspek komponen kawasan menjadi spesifik di Surakarta karena menyangkut transformasi format kedaulatan penguasa dari kerajaan menjadi Negara republik. Periode terakhir adalah ketika Surakarta menjadi bagian dari Negara Kesatuan Republik Indonesia melalui fase pembangunan secara menyeluruh dengan segala dinamika melatarbelakangi pertumbuhan segala aspek kehidupan masyarakat sampai dengan saat ini.

Periode-periode dalam proses tumbuh kembang tersebut telah menjadikan Kota Surakarta menjadi kawasan yang terbentuk oleh kearifan lokal dalam berbagai manifestasi fisik berupa artefak, bangunan dan kelompok bangunan, kawasan bersejarah, sedangkan manifestasi non-fisik berupa seni tradisi musik, tari berkaitan dengan ritual tradisi dan agama. Kearifan lokal terbentuk oleh proses dan produk dinnamika seni budaya komunitas di dalamnya telah menjadi pertimbangan dalam pembelajaran pertumbuhan, perkembangan dan perancangan wilayah kota (Mulyandari, 2011).

Untung dkk dalam penelitian tentang transformasi rumah tradisional di Laweyan Surakarta mengungkapkan bahwa berbagai bentuk rumah Jawa modern yang terlihat saat ini di Laweyan adalah hasil dari proses pemikiran yang matang. Nilai-nilai tradisi atau pemikiran tentang cara membangun rumah harus selalu mengikuti perkembangan waktu dan kebutuhan di antara keluarga Jawa di Laweyan. Orang-orang Laweyan masih 
mempertahankan cara berpikir ini untuk menciptakan rumah yang melindungi dan melindungi (Untung dkk, 2017). Dasar pemikiran ini dapat menjadi acuan model yang mengakomodasi perkembangan kebutuhan masyarakat di Kampung Wisata Blangkon.

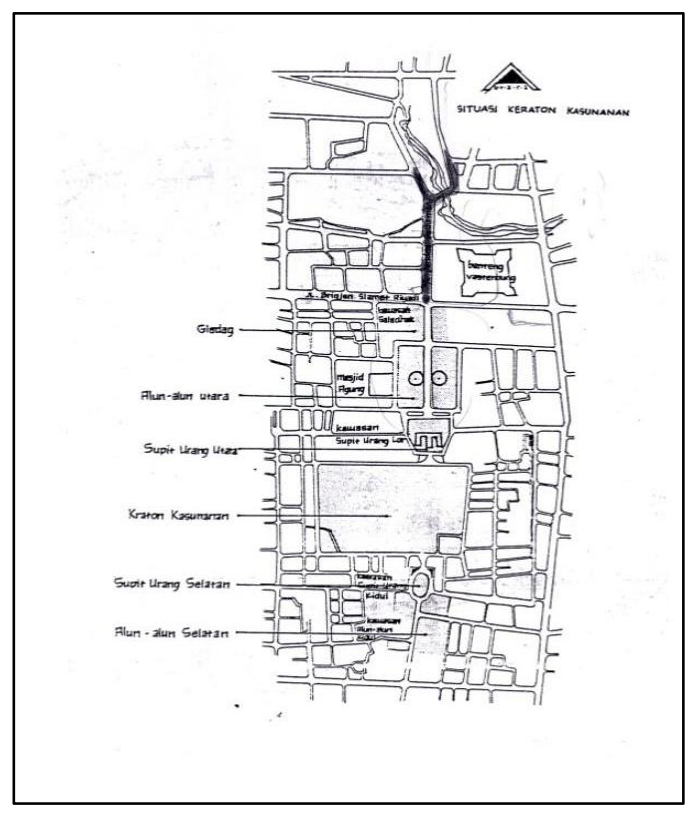

Gambar 1. Peta pusat awal tumbuh kembang Kota Surakarta

Sumber : Sidharta \& Budihardjo

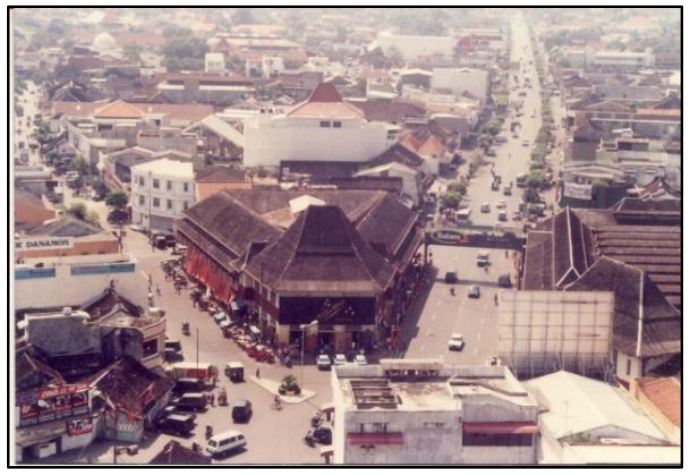

Gambar 2. Kawasan Pasar Hardjonagoro salah satu jejak periode kolonial di Kota Surakarta

Kearifan lokal mulai dirasa perlu dalam era kekinian sekarang dengan indikasi dan gejala intervensi unsur-unsur dari luar negeri tengah melanda pada berbagai sisi kehidupan masyarakat dengan meninggalkan kaidahkaidah yang berbasis pada nilai kelokalan. Salah satu kepentingan adalah untuk membangun sustainabili dalam berbagai proses dan produk. Proses dan produk dalam masyarakat sekarang banyak yang hanya mempunyai umur pendek karena mengabaikan kearifan lokal, hal tersebut seperti yang dialamami tren arsitektur modern yang tidak diterima oleh manusia sebagai pemakainya karena menimbulkan keterasingan (Brolin,1976). Kearifan lokal menjadi lahan yang subur bagi inspirasi dalam membangun kesinambungan emosional sebagai dasar membentuk keterterimaan kehadiran sesuatu yang beru dalam suatu lingkungan yang telah ada sebelumnya.

Pengembangan kampung perlu juga mempertimbangkan kondisi geografis lingkungan. Potensi dan kendala suatu kawasan karena faktor alam sebaiknya mendapatkan prioritas penanganan (Yuliani, 2018). Dalam konteks kampung, teori ini dapat diakomodasi ketika sebuah kampung ternuyata diindikasikan sebagai daerah rawan bencana, misalnya karena faktor banjir, longsor atau angin kencang. Model kampung wisata yang berkelanjutan tentunya mempunyai kebertahanan terhadap alam, mampu meminimalkan resiko yang terjadi dalam bencana. Model pengembangan yang dirancang dapat merespon bahaya akibat bencana dengan seminimal mungkin kerusakan yang mengakibatkan jatuh korban.

Kelurahan Serengan, Kecamatan Serengan Surakarta mempunyai satu kawasan yang terdapat banyak industri blangkon skala rumah tangga. Blangkon adalah salah satu wujud penutup kepala pelengkap busana kejawen. Berdasarkan pengamatan dan data lapangan menujukkan bahwa industri balngkon skala rumahan ini mengalami kondisi stagnan bahkan penurunan dalam beberapa dekade terakhir. Blangkon sebagai komoditi mengalami degradasi dari waktu ke waktu. Titik penjualan dan permintaan pasar positif hanya terjadi beberapa kali dalam satu tahun sehingga dikenal adanya istilah 'musim paceklik', yang makin sering dialami produsen blangkon. Beberapa upaya yang pernah dilakukan untuk memperbaiki keadaan tersebut baik secara mandiri maupun korelatif dengan unsur lain dalam dan luar kawasan namun belum berdampak positif dan berkesinabungan.

Tujuan penelitian adalah mengidentifikasi faktor-faktor penyebab dan akar permasalahan yang berdampak pada karakter pengembangan 
kampung wisata, menemukan solusi yang tepat untuk dasar pertimbangan penentuan arah pengembangan kampung wisata dan menentukan model pengembangan kampung wisata blangkon yang berlokasi di Kelurahan Serengan, Surakarta, seperti disajikan pada Gambar 3. Lokasi penelitian ini merupakan daerah sentra industri rumah tangga yang memproduksi blangkon. Potensi berbasis komunitas dan kondisi lingkungan pada kawasan kampung dan sekitar menjadi fokus perhatian dalam menggali aspek-aspek yang mempunyai prosek positif untuk disinergikan dengan dinamika industri bangkon skala rumahan tersebut. Konsep kearifan lokal digunakan sebagai model kebertahanan kampung, sebagai aspek potensi yang harus dibangun dan dilestarikan menuju peningkatan kemandirian yang berciri khas. Eksplorasi komponen potensi masyarakat sebagai kearifan lokal perlu diperkuat dalam menghadapi interaksi adanya intervensi faktor lain di sekitarnya pada masa mendatang. Kekuatan kearifan lokal digali untuk mendapatkan aspek-aspek selain dinamika produk dan produksi blangkon untuk menambah kebertahanan secara kolektif yang lebih kuat. Beberapa produk kuliner dan seni tradisioanal di Wilayah Surakarta memberikan peluang membangun interaksi sinergis untuk tujuan tersebut. Manifestasi interaksi diwadahi dalam wahana-wahana baru yang potensial dalam rancangan model kampung blangkon.

Beberapa pemahaman esensi suatu model adalah: pola/patron, berbasis fenomena yang berulang dan bisa diaplikasi pada lokasi atau kasus lain yang similar (Pangarso dan Sugiarto, 2014). Pemahaman tersebut memberikan apengertian bahwa dalam proses membangun suatu model membutuhkan komponen dasar berupa kejadian atau fenomena yang berulang dalam jangka lama yang bisa menjadi basis penentuan pola (Kivel,1993). Metoda penelitian berbasis fenomena dibutuhkan dalam proses pendataan, analisa dan sintesa menuju simpulan sebagai target akhir.

Penelitian tentang pengembangan kampung wisata dengan daya dukung kearifan lokal telah dilakukan di beberapa kampung wisata di Indonesia, namun penelitian yang mengangkat tema kampung wisata blangkon masih sedikit informasi yang diperoleh. Walaupun upaya pengembangan kampung wisata berciri khusus untuk perkuatan pemberdayaan masyarakat telah banyak dilakukan, akan tetapi pengkayaan jenis komiditi yang sangat relevan dengan budaya dan ekonomi masih perlu diinventarisasi, salah satunya komiditi blangkon. Karena blangkon merupakan bagian dari perangkat pakaian tradisional yang mempunyai ciri khusus, bahkan berpeluang untuk menjadi warisan budaya Indonesia yang perlu mendapat pengakuan dunia melalui UNESCO, sebagai suatu badan dalam naungan PBB untuk bidang kebudayaan.

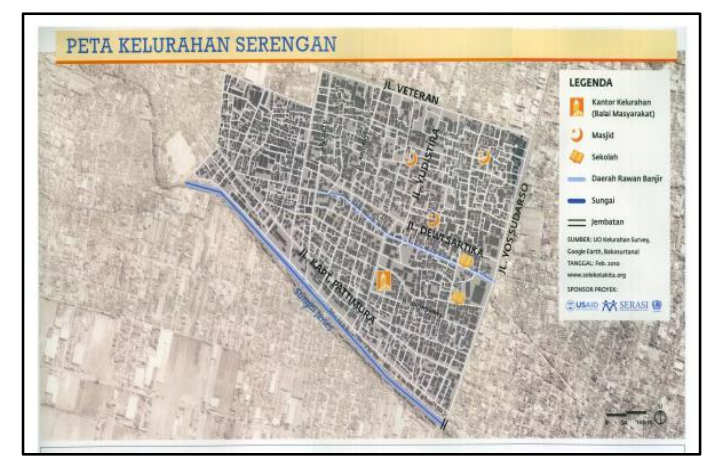

Gambar 3. Peta Kelurahan Serengan Sumber : DTRK Surakarta

\section{METODE}

Metode kualitatif fenomenologi dengan analisis semiotik (Afifuddin \& Saebani, 2009) digunakan dalam proses penelitian ini. Fenomenologi berusaha untuk memahami arti peristiwa dan kaitannya dengan manusia dan lingkungan dalam situasi tertentu (Moleong, 2018). Penelitian dibangun dengan mempertimbangkan temuan dari pengamatan secara mendalam pada obyek penelitian dan informan yang merupakan masyarakat dan aparat pemerintah Kelurahan di Kampung Wisata Blangko, Serengan. Pengamatan kejadian dan dinamika lapangan rentang waktu beberapa tahun ke belakang sampai dengan sekarang dengan memanfaatkan data dan observasi langsung. Metode ini tepat digunakan sebagai acuan mekanisme penelitian mulai dari penjaringan dan perumusan masalah, penjaringan unsur-unsur yang mempuyai prospek bersinergi dengan nucleus dan kemungkinan solusi pemodelan sebagai target akhir. 
Metode ini terdiri dari tiga tahap pokok, yaitu penentuan model mencakup komponen dan interaksi; mekanisme operasional model; dan membangun sustainability/kebertahanan model dalam dinamika faktor pengaruh saat ini dantang akana datang. Tahap penjaringan untuk menentukan komponen model berakar pada pemahaman aspek-aspek yang membentuk permasalahan berkaitan dengan kurang atau tidak berkembangnya industri blangkon skala rumah tangga baik dari sisi internal maupun eksternal. Salah satu mekanisme penting adalah pemahamman blangkon sebagai basis komponen kampung wisata. Permasalahan penting yang menerpa produk dan produksi blangkon adalah eksistensi, sustainabilitas dan durabilitas. Kronologi pembahasan fokus pada diskripsi ketika aspek-aspek terebut berkaitan dengan bahan dasar, permintaan pasar, kesempatan dan dukungan. Bahan dasar blangkon berkaitan dengan material dan disain selama ini meskipun telah diupayakan perbaikan tetapi masih kurang mampu berperan serta dalam dinamika kolektif dengan aspek atau produk lain. Dinamika bahn dasar tersebut berakibat pada kurang berkembangnya volume permintaan pasar yang seolah statis. Tumbuh kembang tren kampong wisata spesifik berbasis kearifan lokal selama 5 th terakhir menjadi satu kesempatan emas bagi produk dan proses produksi blangkon menjadi embriyo dan kemudian dengan aspek kearifan lokal lain secara bersama membangun kawasan wisata spesifik. Proses tersebut sangat prospektif dalam mencari dukungan berbagai pihak karena memberi kesempatan lebih luas. Kawasan wisata spesifik yang terbentuk memberikan akomodasi interaksi pihak-pihak dengan masing-masing kepentingan non profit dan profit. Kronologi penelusuran pemahaman blangkon secara korelatif seperti demikian memberikan gambaran peluang blangkon menjadi produk seni tradisi dan komoditi secara simultan.

Kajian berikutnya adalah inventarisasi aspekaspek yang mempunyai prospek positif untuk bersinergi dengan dinamika eksistensi dan keberlangsungan produk, proses produksi blangkon, dirangkai dalam skema yang terdapat pada Gambar 4. Kelurahan Serengan merupakan salah satu kawasan dengan beberapa produk/aspek berbasis kearifan lokal dan ekonomi kerakyatan. Aspek berbasis seni tradisi berupa seni gamelan, pewayangan, tari jawa/ tradisional daerah lain, musik keroncong. Bentuk-bentuk interaksi antara potensi yang telah teridentifikasi harus memberikan peluang terwujudnya kesatuan yang sinergis.

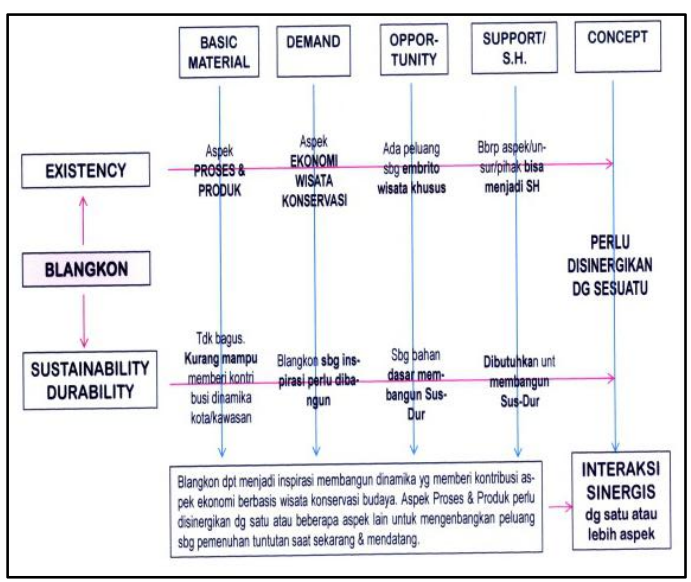

Gambar 4. Bagan proses pemahaman blangkon sebagai potensi kelokalan

Kajian terakhir fase ini adalah membangun model interaksi aspek fokus berupa produk dan proses produksi blankon dengan aspek-aspek yang prospektif bersinergi dengan komponen focus sehingga membangun keberdayaan dan kebertahanan secara bersama. Beberapa model interaksi yang mempunyai prospek positif adalah interaksi langsung dan tidak langsung, yang ditentukan oleh terciptanya suasana atau atmosfir yang rekreatif. Model interaksi langsung terjadi pada jalan/gang yang berbatasan langsung dengan fasade rumah produksi ketika pengunjung mempunyai kesempatann komunikasi /kontak dengan produk dan proses produksi blangkon, meskipun terdapat pembatasan krarena alasan kelancaran dan keamanan. Interakksi langsung juga terjadi pada kegiatan pembelajaran dan tutorial pembuatan blangkon dan pagelaran interaktif beberapa seni tradisi yang diakomodasi dalan area pameran dan pagelaran.

Tahap kedua adalah menentukan mekanisme operasional model yang merupakan pengaturan jadwal pelaksanaan model komponen dan interaksi yang telah disimpulkan, dikelompokkan menjadi regular dan nonreguler. Beberapa bentuk penjadwalan adalah yang pertama, interaksi langsung antara 
pengunjung dengan produk dan proses produksi di jalan/gang fokus harus dibatasi demi kepentingan dan kenyamanan bersama. Jam-jam yang kondusif adalah jam 10.00 sampai dengan jam 15.00. Kedua, interaksi langsung antara pengunjung dengan kegiatan non-produksi bisa lebih diatur sesuai dengan kepentingan dan harus tetap membentuk atmosfir yang kondusif bagi kegiatan lain. Contoh pengkondisian adalah ketika diadakan pagelaran atau peragan seni tradisi harus diadakan pada waktu yang tepat supaya keramaian yang terjadi tetap kondusif kegiatan penikmatan produk blangkon. Ketiga, keterbatasan lahan Kampung Blangkon membutuhkan areal fisik untuk fasilitasfasilitas pendukung dalam operasionalnya saat ini dan perkembangan mendatang seperti pola sirkulasi dan lahan/kantung parkir. Permasalahan ini dipecahkan dengan mencarikan lahan-lahan disekitar lokasi kasus. Permasalahan ini dipecahkan dengan mencarikan lahan-lahan disekitar lokasi kasus.

Tahap ketiga adalah membangun kebertahanan (sustainability) model dalam menghadapi faktor-faktor degradatif. Mekanisme ini dilakukan dengan membangun interkasi dengan eksternal model baik secara nyata maupun jejaring maya. Jejaring sosial dimanfaatkan untuk penyebaran informasi tentang eksistensi kampung blangkon sebagai wahana dinamika ekonomi kerakyatan dan rekreasi budaya.

Pengumpulan data dilakukan secara bertahap dari informan dan sumber sekunder serta pengamatan secara langsung di lapangan dengan merekam kejadian. Analisis menggunakan semiotik dilakukan pada waktu pengamatan dan wawancara dengan informan. Selanjutnya hasil analisis dilakukan verifikasi untuk menentukan temuan secara diskriptif, ilustratif dan simulatif yang disusun menjadi sebuah pemodelan.

\section{HASIL DAN PEMBAHASAN}

Aspek pokok yang perlu dibahas berkaitan dengan Wujud pemodelan hasil penelitian ini adalah komponen model, operasional model dan kebertahanan model. Komponen model adalah aspek pembentuk morfologi model terdiri dari komponen inti, komponen pendukung internal dan komonen pendukung eksternal. Operasional model berkaitan dengan mekanisme kelola ketika komponen model berfungsi mengarah pada pengaturan waktu dan periode fungsi masing-masing komponen dan ketika berfungsi secara simultan. Kebertahanan model merupakan rumusan mekanisme upaya membentuk kebertahanan terhadap faktor degradatif internal dan eksternal model, seperti pada Gambar 5.

Komponen inti berupa bentuk, dimensi dan ekspresi satuan maupun komposisi unit rumah sebagai wadah aktivitas produksi blangkon. Kondisi eksisting komponen ini adalah ketidak-teraturan yang merupakan faktor tidak kondusif untuk suatu proses komunikasi visul yang merupakan stimulan awal beberapa proses lanjut mengarah pada apresiasi dan minat beli produk blangkon. Dinamika kehidupan kesehrian berbaur dengan proses produksi cukup mengganggu kenyamanan interaksi antara pengunjung dengan blangkon. Pada bagian ini dilakukan konsep tindakan 'merapikan' ruang-ruang dalam rumah produksi sedemikian sehingga lebih kondusif untuk proses komunikasi visual dan penikmatan produk blangkon dengan pengunjung/peminat.

Komponen pendukung internal adalah sarana pendung dalam kawasan yang membentuk atmosfir wisata berupa jalur sirkulasi, street wall exposition, taman vertikal, wahana pameran, workshop produk seni tradisi dan perpustakaan spesifik. Pertimbangan penting dalam kajian komponen ini adalah letak dan lusan harus tepat pada kawasan kasus. Komponen wahana pameran, area pagelaran seni dan workshop cukup tepat berada di tengah kawasan dengan menempati bekas makam yang mempunyai luasan sukup proporsional. Posisi dan luasan tersebut memberikan kesempatan alur dan interaksi yang sinergis dengan kegiatan lain, sebagai gambaran ketika terjadi pemusatan kegiatan pada zona pendukung unternak tidak akan mengganggu kegiatan di koridor utama.

Jalur sirkulasi perlu dirapikan dan diatur arah masuk keluar kawasan. Upaya ini untuk memperbaiki interaksi langsung antara pengunjung dengan fasade fasade rumah produksi blangkon sebagai upaya membenahi 
komunikasi visual orang/pengunjung yang berada di gang dengan minimal fasade rumahrumah produksi. Penambahan beberapa komponen perabot jalan berupa taman vertical, peneduh dan tempat pajang blangkon dan barang seni tradisi lain dari internal dan eksternal kawasan. Tujuan pengaturan jalan menjadi satu arah memberikan kenyamanan gerk pengunjung yang kemudian mendukung perbaikan komunikasi visual antara produk dan produksi blangkon dengan pengunjung. Komponen tersebut merupakan upaya membangun atmosfir rekreatif kawasan kasus. Kegiatan komplemen yang lebih komplek seperti pameran produk seni tradisi, pentas seni tradisi diakomodasi dalam ruang multi guna. Kegiatan-kegiatan yang membutuhkan konsentrasi lebih intensif dilakukan dalam wahana workshop dan perpustakaan khusus. Fasilitas terakhir yang harus melengkapi yang telah ada adalah toilet umum pada posisi yang tepat.

Komponen pendukung eksternal adalah sarana pendukung di luar kawasan inti berupa jalur sirkulasi terdekat, eksisting sentra industri setara atau di atasnya, serta tubuh kembang seni tradisi dan produk komoditi yang menyertai. Kawasan kasus penelitian berada pada posisi dan situasi yang strategis dalam wilayah kecamatan dan kota, tetapi dalam kondisi yang sangat terbatas karena tingkat kepadatan sangat tinggi sehingga diperlukan koordinsi dengan lokasi terdekat dan berikutnya. Kebutuhan zona transit di luar kawasan kasus bagi pengunjung sangat dibutuhkan karena sudah tidak terdapat alokasi tanah. Koordinasi yang tepat perlu dilakukan untuk mendapatkan koneksi alur sirkulasi yang saling mendukung.

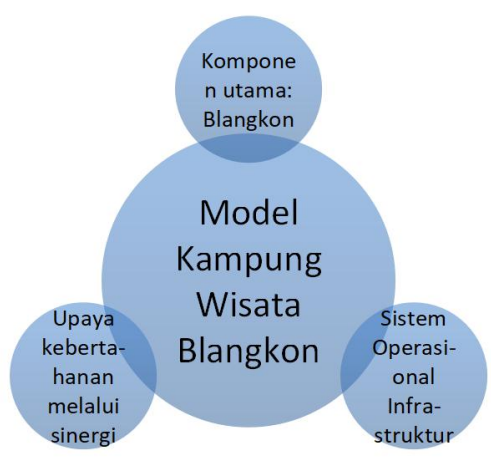

mbar 5. Tiga unsur model pengembangan. Ga
Hal ini menjadikan analisis interaksi zona internal dengan eksternal harus cermat untuk mendapatkan model interaksi yang sinergis antara kedua komponen tersebut, mencakup jalur sirkulasi, peta potensi kearifan lokal dalam skala kelurahan, kecamatan, kota dan provinsi.

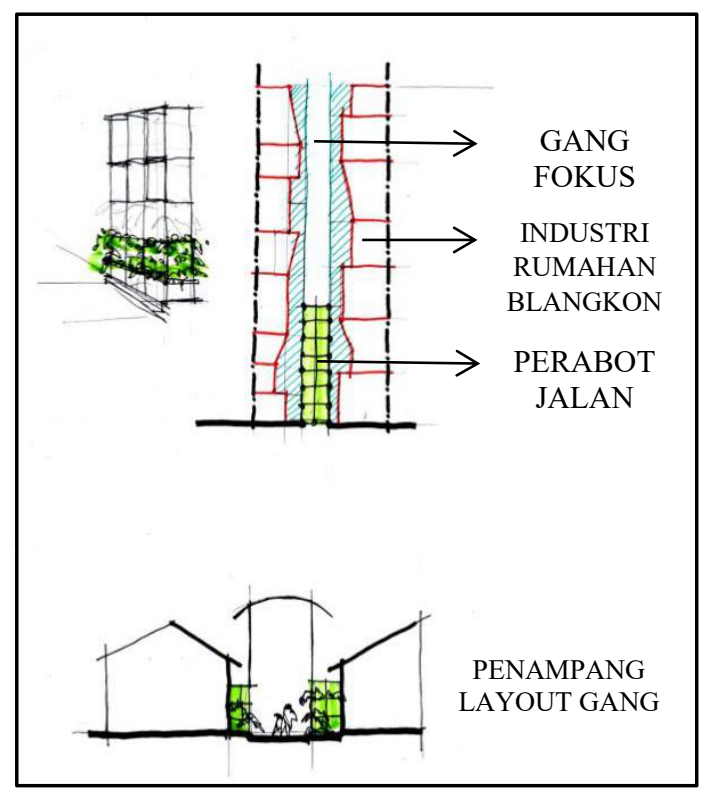

Gambar 6. Ilustrasi Model Penataan Gang

Sasaran pokok dari operasional model yang dihasilkan adalah meningkatkan eksistensi, keberdayaan yang akan membentuk kelangsungan blangkon sebagai produk seni tradisi dan komoditi. Dinamika interaksi sinergis antar komponen ditampilkan dalam Gambar 6 dan Gambar 7, mempunyai penjelasan pemodelan berupa kronologi sebagai berikut:

- Membangun komunikasi visual awal antara produk dan proses produksi dengan pengunjung sebagai stimulan tindak lanjut. Proses ini terjadi pada zona inti berupa jalan/gang dengan kedua sisi bersinggungan langsung dengan garis fasade rumah-rumah industry blangkon secara berderet arah timur barat.

- Membangun minat individu, kelompok terhadap blagkon dalam berbagai kepentingan, baik seni tradisi dan komoditi melalui interaksi sinergis dengan produk dan aktivitas lain. Proses ini berlangsung dalam zona pendukung internal dan eksternal. Kegiatan ini berupa pelatihan berkaitan 
dengan produksi dan kreasi berbasis blangkon.

- Membangun apresiasi dan kemanfaatan akan blankon yang lebih variatif untuk kemungkin nan mencapai dan menjaga volume produksi yang tinggi. Kegiatan ini pada dasarnya mengembangkan kegiatan yang telah ada dan membuka peluang baru bagi penjualan dan pemakaian blangkon yang lebih luas. Proses ini berlangsung dalam zona pendukung internal dan eksternal.

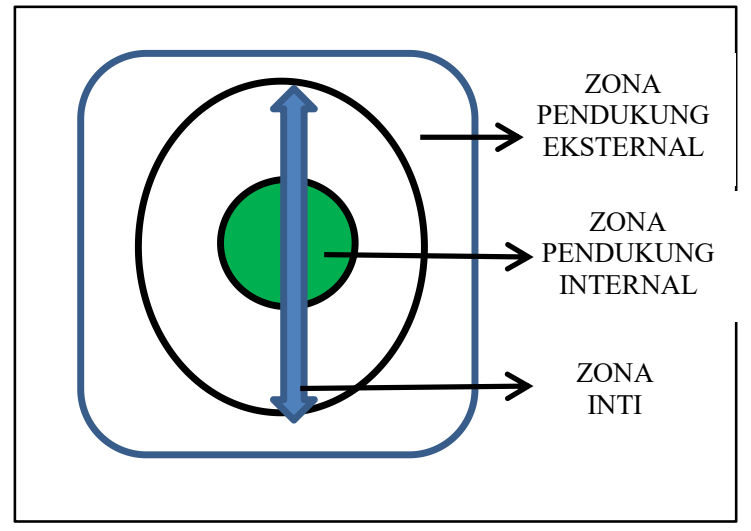

Gambar 7. Ilustrasi Komponen Model Kampung Wisata Berbasis Kearifan Lokal

Kronologi tersebut harus berlangsung dalam atmosfir wisata melalui mekanisme kelola urutan dan waktu kegiatan dalam pewadahan yang tepat, hal ini penting karena pengunjung dan penikmat pemodelan dalam rentang yang lebar baik usia, klas sosial dan tempat asal mereka.

Mekanisme operasional komponen model mencakup internal dan eksternal kawasan. Operasional model internal harus dilakukan secara tepat karena terjadi proses interaksi yang sensitif antara zona hunian dengan wisata karena keduanya berbeda karakter; namun demikian kasus di kawasan kasus mempunyai konsekuensi lebih ringan dengan adanya suasana transisi rumah yang juga merupakan ruang produksi blangkon. Operasional model secara eksternal perlu mengaitkan kawasan kasus dengan kawasan sekitarnya secara sinergis. Beberapa titik kawasan terdekat dan selanjutnya merupakan pusat kegiatan ekonomi yang cukup dinamis seperti pertokoan, pasar, restoran. Hal ini memberikan rambu-rambu jam dan durasi operasional untuk saling menyesuaikan.

Kawasan kasus juga harus menjadi bagian yang harmonis dan menyatu dari jaringanjaringan wisata dan pariwisata yang telah ada sebelumnya sehingga membentuk satu kesatuan operasional sistim yang lebih luas. Tidak hanya dalam kawasan Kota Surakarta tetapi dengan kota-kota minimal di Jawa Tengan yang telah memiliki kampungkampung wisata seperti Provinsi Daerah Istimewa Yogyakarta.

Aspek yang perlu dibahas berkaitan dengan kebertahanan model Kampung Wisata Blangkon Serengan adalah faktor degradatif yang terjadi, strategi untuk menahan dan mengatasi faktor degradatif dan strategi mempertahankan serta memperkuat kebertahanan model. Faktor yang bisa menyebabkan penurunan kualitas model kawasan kasus berasal dari internal dan eksternal kawasan. Faktor internal berkaitan dengan dinamika aktivitas dan etika pelaku aktivitas mempunyai dinamika dampak bergantung pada ketaatan dan kesadaran pelaku aktivitas dalam memahami dan mentaati tata atur oprasional model. Dampakdampak negatif akan terjadi apabila terjadi pelanggaran manajemen operasional model oleh semua pihak pelaku aktivitas. Faktor eksternal adalah pengaruh berasal dari luar kawasan model berkaitan dengan pelaku dan dinamika aktivitas dalam berbagai bentuk. Kualitas kebertahanan model kasus dibangun dengan memanfaatkan komponen eksternal dan jejaring sosial baik secara mandiri maupun kolektif. Pemanfaatan komponen internal dalam kawasan kasus membutuhkan pendekatan yang tepat karena pola kepadatan dan mekanisme guna persil-persil kawasan. Fasilitas-fasilitas baru yang akan dihadirkan meskipun telah ada alokasi lahan bekas pekuburan tetapi terlrtak pada bagian sentral dengan kepadatan huni yang padat dengan pola tidak beraturan. Disain interaksi antara keduanya juga harus membentuk jalur sirkulasi yang harmonis dengan model. Komponen fasilitas eksternal yang paling membutuhkan perhatian dan tindakan sejak perencanaan adalah kronologi interaksi jalur dalam dengan luar kawasan model; dan fasilitas parkir kendaraan baik bermotor, tidak bermotor, roda 
dua maupun roda empat. Hal ini berkaitan dengan kondisi eksisting internal maupun eksternal kawasan kasus yang sudah sangat padat dan terletak pada posisi strategis dalam cakupan kota Surakarta sehingga membutuhkan proses pembahasan pendekatan dalam membangun interaksi sinergis menuju kondisi kebertahanan bersama.

Mekanisme untuk mempertahankan dan mengembangkan model yang bisa dilakukannadalah dengan memanfaatkan jejaring interaktif sebagai sarana promosi dan informasi Kampung Wisata Blangkon Serengan baik sebagai wahana komersial maupun rekreasi. Kampung Blangkon sebagai tujuan wisata budaya dapat menjadi satu bagian dari jejaring promosi wisata budaya khuusnya heritage bersama dengan komponen lain dalam tataran wilayah kota, provinsi, nasional dan internasional. Upaya yang telah diakukan oleh Kelurahan Serengan dan yang terkait perlu untuk ditingkatkan dengan menambah cakupan dan jumlah pihak kedua sebagai upaya untuk mengembangkan kreativitas bentuk dan wahana komunikasi.

\section{KESIMPULAN}

Kampung Blangkon sebagai satu model kawasan wisata budaya memberikan gambaran potensi dan prospek positif dalam mengembangkan dan meningkatkan nilai apresiasi dan ekonomi bagi komponen internal dan eksternal dalam suatu ninamika interaksi sinergis.

Kearifan lokal dengan berbagai manifestasi merupakan sumber inspirasi bagi upaya-upaya membangun dan memperkuat keberdayaan komunitas. Kegiatan-kegiatan berbasis kearifan lokal dalam kenyataan menunjukkan peran penting menghadapi gejolak berbagai aspek, sosial, ekonomi bahkan politik pemerintahan.

Pemodelan yang dihasilkan penelitian ini terbentuk oleh tiga unsur pokok model, yaitu : komponen, cara operasional dan strategi kebertahanan, yang diharapkan mampu membangun eksistensi, keberdayaan dan kelangsungan blangkon sebagai produk seni tradisi dan komoditi. Kampung wisata blangkon memberikan kesempatan produk dan kegiatan lain berbasis potensi kelokalan dari internal dan eksternal kawasan kasus untuk bertahan dan berkembang secara bersama dan sinergis. Unsur komponen merupakan instrumen penting yang menjadi produk unggulan khas kampung wisata. Komponen ini akan menjadi pembeda dengan kampung wisata lain, dimana dalam penelitian ini komponen khas adalah blangkon. Unsur kedua, cara operasional dalam penataan kawasan kampung, penentuan dan pembagian zona yang beradaptasi dengan lingkungan dan mengakomodasi kegiatan masyarakat kampung. Unsur ketiga, upaya kebertahanan, melalui model interaksi secara sinergi yang dituangkan dalam tatanan masa fisik yang mencakup ruang privacy dan ruang komunal.

Istilah interaksi sinergis perlu dipahami secara proporsional karena menyangkut beberapa kepentingan yang perlu pemisahan sekaligus harus interaksi dalam kemanfaatan bersama. Kegiatan industri rumahan blangkon membutuhkan fasilitas pewadahan dengan pengkondisian sesuai standard keamanan kerja sedangkan kegiatan wisata dan pembelajaran membutuhkan atmosfir yang spesifik pula. Satu strategi rancang bangun yang tepat dibutuhkan untuk memanifestasikan pemahaman interaksi sinergis dalam satu keputusan desain atau redesain.

Strategi rancang bangun sebagai tindak lanjut pemodelan akan sangat tepat menerapkan metode berbasis peran serta komunitas khususnya di dalam lokasi kasus karena mereka berperan sebagai pelaku utama mekanisme operasionalnya.

Pihak pihak baik individu, komunitas dan institusi berada internal dan eksternal kawasan yang berkepentingan langsung atau tidak langsung sangat potensial untuk dilibatkan dalam proses rancang bangun sejak tahap konsep sampai dengan keputusan disain. Hal ini merupakan satu jaminan model dan bangunan yang terbentuk tetap menyatu dengan komunitas yang telah ada sebelumnya.

Temuan model pengembangan Kampung Wisata Blangkon terdapat tiga komponen yang disinergikan dalam pengolahan tata ruang berdasarkan kebutuhan dari kegiatan masayrakat yang tinggal di kawasan kampung dan sekitarnya, sehingga ruang-ruang yang terbentuk memiliki kekuatan untuk mampu 
bertahan terhadap intervensi luar. Tiga unsur meliputi komponen pemberi identitas diakomodasi dalam penataan ruang dan infrastruktur yang mendukung keberlanjutan kawasan baik lingkungan dan kebutuhan kehidupan mendasar masyarakat merupakan kebaharuan dan model pengembangan kampung wisata berbasis kearifan lokal.

Model Kampung Wisata Blangkon di Kelurahan Serengan ini juga diharapkan dapat diaplikasi pada lokasi, kawasan lain yang mempunyai permasalahan dan potensi kelokalan yang setara.

\section{UCAPAN TERIMAKASIH}

Penelitian ini berlangsung dengan baik karena dukungan dalam berbagai bentuk beberapa pihak baik individu maupun instansi, yaitu Kepala wilayah dan staf Kelurahan Serengan, Kecamatan Serengan dan Pemerintah Kota Surakarta yang telah memberikan ijin melakukan penelitian di kawasan kasus, menjadi nara sumber dan fasilitator antara peneliti dengan pihak-pihak terkait dengan materi dan proses penelitian. Juga kepada beberapa satuan dinas di lingkungan Pemerintah Kota Surakarta yang sempat menjadi mitra selama proses penelitian. Selain itu, kepada masyarakat komunitas industri blangkon skala rumah tangga sebagi bagian dari fokus penelitian yang telah menjadi bagian penting dari materi dan proses penelitian. Beberapa lembaga dan perorangan swadaya pemerhati seni budaya tradisi di Wilayah Surakarta serta kolega di Program Studi Arsitektur FT UNS, khususnya anggota Grup Riset Arsitektur Berkelanjutan, yang telah memberikan dukungan semangat selama proses penelitian dengan koreksi dan masukan yang konstruktif sehingga menjadikan hasil penelitian menjadi optimal meskipun masih perlu pembenahan dan penyempurnaan di beberapa bagian.

\section{REFERENSI}

Afifuddin \& Saebani (2009). Metodologi Penelitian Kualitatif. CV. Pustaka Setia, Bandung.

Brolin, Brent C (1976). The Failure of Modern Arcitecture. Van Nostrand Reinhold Comp. New York.
Untung Joko Cahyono, Bambang Setioko \& Titin Woro Murtini (2017). Transformation of form in the growth of modern Javanese house in Laweyan Surakarta, Journal of Architecture and Urbanism, 41:4, 288-295.

Kivel, P. (1993). Land and the City, Patterns and Processes of Urban Change. Routladge, London and New York.

Moleong, Lexy. (2018). Metodologi Penelitian Kualitatif. Bandung: PT. Remaja Rosdakarta, Cetakan ke-38.

Mulyandari, H.(2011). Pengantar Arsitektur Kota. Penerbit Andi, Yogyakarta.

Pangarso, P, FX. \& Sugiarto R, Y. (2014). Teknik Pendekatan Disain Bentuk Estetis Arsitektural. PT. KanisiusYogyakarta.

Setyaningsih, W. (2015). Community Based Tourism. UNS Press, Surakarta.

Sidharta \& Budihardjo, E (1989). Konservasi Lingkungan dan Bangunan Kuno Bersejarah di Surakarta. Gadjah Mada University Press, Yogyakarta.

Sutedjo, S.B. (1985). Pencerminan Nilai Budaya dalam Arsitektur di Indonesia. Penerbit Djambatan Jakarta.

Tosun, C. (2000). Limits to Community Participation in the Tourism Development Process in Developing Countries. Tourism Management, (2000) 613-633.

Yuliani, Sri., Setyaningsih, Wiwik., Winarto, Yosafat. (2018). Strategi Penataan Kawasan Pantai Klayar Pacitan Sebagai Destinasi Pariwisata Berkelanjutan Dengan Prinsip Arsitektur Ekologis. Jurnal RUAS, Volume 16 No 2 Desember 2018, ISSN 1693-3702, E-ISSN 2477-6033.

Zahnd, M. (2008). Model Baru Perencaanaan Kota yang Kontekstual, Kajian tentang kawasan tradisional di Kota Semarang dan Yogyakarta suatu potensi perancangan kota yang efektif. Soegijopranata University Press, Semarang. 